\title{
Assessment on the allocation of Cash Grants of 4Ps beneficiaries to their daily Expenditures
}

\author{
Fhrizz S. De Jesus, мBA, LPT; Rommel R. Rivera, мBA
}

\begin{abstract}
This study aims to determine where the 4Ps beneficiaries allocate the cash grants they receive from the government on their daily expenditures in terms of Education, Food, Transportation, Clothing, Entertainment, and Other bills. This study was conducted on seventeen barangays of Laur, Nueva Ecija with total number of $3374 P$ s beneficiaries as respondents. Descriptive research was used through the survey questionnaire and interviews to answer the research problem. Based from the result, the education was highly prioritized. The researchers formulated a recommendation that may help 4Ps beneficiaries on spending their grants.
\end{abstract}

Keywords - Cash Grants, daily Expenditures, 4Ps beneficiaries.

\section{INTRODUCTION}

According to Casco, Lam, Lumantas, and Magno (2015), The Philippine government implemented the Pantawid Pamilyang Pilipino Program (4Ps) and patterned it after Latin American conditional cash transfer (CCT) programs, with the goals of poverty reduction and social development. Pantawid Pamilyang Pilipino Program, also known as 4Ps and formerly Ahon Pamilyang Pilipino, is a Conditional Cash Transfer program of the Philippine government under the Department of Social Welfare and Development.

Frufonga (2016), mentioned that one factor that is associated to the health status of an individual is poverty. According to the study of Institute of Family Life and Children's Studies Philippine Women's University (October 26, 2016), it aims to eradicate extreme poverty in the Philippines by investing in health and education particularly in age 0-14.It is patterned on programs in other developing countries like Brazil (Bolsa Familia) and Mexico (Oportunidades).

As extracted from the official website of Pantawid Pamilyang Pilipino Program (Pantawid.dswd.gov.ph), the 4Ps program now operates in 17 regions, 79 provinces and 1,484 municipalities and 143 key cities covering 4,876,123 poor households nationwide as of December 31, 2018.

According to the study of Institute of Family Life and Children's Studies - Philippine Women's University (October 26, 2016), conditional cash transfers (CCT) are essentially providing financial incentives or resources to underprivileged families in exchange for their agreements to a set of conditions aimed at cultivating their capacities. More often than not, the conditionality is linked to education and health outcomes to address the chronic poverty of the household. As extracted from (Pantawid.dswd.gov.ph), The
Philippines' version of the CCT is the Pantawid Pamilyang Pilipino Program (hereinafter referred as Pantawid). As mentioned in studylib.net, it has two goals: (1) alleviation of immediate income poverty (social assistance), and (2) break the intergenerational cycle of poverty through human capital investments and nutrition (social development). It targets the "poorest of the poor" in the country, and as beneficiaries, they receive a monthly cash grant of $\mathrm{PhP} 500$ for health expenses, and $\mathrm{PhP} 300$ per school child member in elementary school or PhP 500 if the child is in high school (maximum of three children) (Pantawid.dswd.gov.ph). The program was formally launched in 2008 with 360,000 household recipients; by 2015, the number of beneficiaries was 4.4 million. The latest evaluations of the Pantawid show its positive impact on the concerns directly targeted by the conditionality i.e. in children's education (there is an increased enrolment rate in primary schools in the Pantawid communities) and health (more mothers are going to health centers for professional maternal health services and health guidance in general, more children are receiving vaccines and regular de-worming, the household has increased their food intake). Based from Flores, Espinoza, Enrico, and Casimiro (2015), it is therefore recommended that the scope of the program be extended especially that two years have been added to the secondary education. However, there is a need to assess changes beyond the compliance of households to the Pantawid conditionality and how the positive impact of the program be sustained after its beneficiaries have "graduated" from the program. It is noted that one of the goals of the conditional cash handover program is to break the intergenerational series of poverty. Thus it is even more vital that the positive changes resulting from the program 
should not be dependent on the cash grant currently being received, rather it is because the beneficiaries are already empowered to create environments, whether within their households or in their community, where their rights to education, health, and development are realized.

The purpose of this study is to find out where the 4Ps beneficiaries commonly used the cash grants they receive from the government on their daily and other expenditures. The researchers believe that the outcome of this study can be helpful for 4Ps beneficiaries and the government.

\section{OBJECTIVES OF THE PROBLEM}

This study was based on the study of Arnold Q. Malaluan, Gleziel M. Malaluan, Regine T. Leyesa, Kathleen H. Malayba and Marissa H. Perez (2018) entitled "Financial Priorities of 4p's Beneficiaries: An Assessment Using First Bucket Theory".

This study attempted to describe and assess the allocation of cash grants of $4 \mathrm{ps}$ beneficiaries to their daily expenditures.

Specifically, the study sought to answers the following:

1. How may the demographic profile be described in terms of:

- Sex

- Age

- Number of dependents

- Amount of Grants Received

- Number of Pantawid children in Household

- Educational Attainment

2. How does the cash grant helped the daily expenditures of the family in terms of:

- Education

- Food

- Transportation

- Clothing

- Entertainment

- Other Bills

\section{METHODOLOGY}

The study used descriptive method to determine how the allocation of cash grants of 4Ps beneficiaries of Laur, Nueva Ecija were affected by their personal profile.

The research instrument used was survey method and interview, wherein respondents answered questions administered through questionnaires and interviews.
The instrument was formulated in the modified 4-point likert scale ranging from always (4), sometimes (3), seldom (2), never (1). Respondents were then instructed to rate the statements and answer the questions.

The data collected from the locale were encoded, tallied and analyzed using the following statistical tools were used. Data presentation of the given scale was used to interpret the results of the information gathered:

To determine the respondents' degree of perception, the weighted mean was computed using the following formula: Weighted mean $(\Sigma W M)$ is equal to total weighted frequency $(\Sigma \mathrm{WF})$ divided by the total number of cases $(\mathrm{F})$.

The percentage frequency distribution was computed using the formula: frequency $(\mathrm{F})$ divided by the sample $(\mathrm{N})$ and multiply by one hundred (100). The researchers used ranking to compare items to each other by placing them in order of preferences.

\section{RESULTS AND DISCUSSION}

According to the gathered data:

Table 1. Demographic Profile according to Sex

\begin{tabular}{|l|c|c|}
\hline PROFILE VARIABLE & F & $\%$ \\
\hline \multicolumn{1}{|c|}{ SEX } & & \\
\hline MALE & 82 & $24 \%$ \\
\hline FEMALE & 255 & $76 \%$ \\
\hline
\end{tabular}

Table 1 shows Distribution of the respondents according to Sex. Most of the respondents were Female with a number of 255 or $76 \%$ compared to just 82 or $24 \%$ of the Male respondents.

Male were supposed to be the beneficiary of the cash grants because they were the head of the family. But since they spent more of their time on working, they were rarely present on attending the Family Development Session (FDS), an activity where all the beneficiaries must be present or else the cash grants to be received will be deducted. So they transferred the honors to female beneficiaries knowing that they were usually staying on their houses.

Table 2.Demographic Profile according to Age

\begin{tabular}{|c|c|c|}
\hline Age & Frequency & Percentage \\
\hline $21-30$ & 28 & $8 \%$ \\
\hline $31-40$ & 120 & $36 \%$ \\
\hline $41-50$ & 119 & $35 \%$ \\
\hline $\begin{array}{c}51 \text { YEARS } \\
\text { OLD ABOVE }\end{array}$ & 70 & $21 \%$ \\
\hline
\end{tabular}


Table 2 shows Distribution of the respondents according to Age. Most of the respondents were ages 31-40 years old with a number of 120 or $36 \%$ of the sample, not too far from the respondents aged 41-50 years old with a number of 119 or $35 \%$ of the samples.

31-40 and 41-50 years old were the common age of having a family wherein the children were all studying and must have a stable financial support in terms of education.

Table 3. Demographic Profile according to Number of Dependents

\begin{tabular}{|c|c|c|}
\hline Number of Dependents & Frequency & Percentage \\
\hline $1-3$ & 128 & $38 \%$ \\
\hline $4-6$ & 146 & $43 \%$ \\
\hline 7 ABOVE & 63 & $19 \%$ \\
\hline
\end{tabular}

Table 3 shows Distribution of the respondents according to Number of Dependents. Most of the respondents have 4-6 dependents with a number of 146 or $43 \%$ of the total sample. Dependents were those aged under 16 years old living with at least one parent, or aged 16 to 18 in full-time education, excluding all children who have spouse, partner or child living in the household.

Table 4. Demographic Profile according to Amount Received

\begin{tabular}{|l|c|c|}
\hline Amounts Receive & Frequency & Percentage \\
\hline Php1,000-2,500 & 77 & $23 \%$ \\
\hline Php2,501-4,000 & 84 & $25 \%$ \\
\hline Php4,001 ABOVE & 176 & $52 \%$ \\
\hline
\end{tabular}

Table 4 shows distribution of the respondents according the Amounts Receive. When it comes to the amounts of grants received, 176 respondents or $52 \%$ of the total samples were receiving Php4,001 and above of cash grants.

Amount of grants received was based accordingly to how many benefited children studying there in 4Ps family. Another factor is the interval of date that the cash grants will be given (i.e. every 2 months, every 3 months.)

Table 5. Demographic Profile according to the Number of

\section{Pantawid Children}

\begin{tabular}{|l|l|l|}
\hline $\begin{array}{l}\text { Number of } \\
\text { Pantawid Children }\end{array}$ & Frequency & Percentage \\
\hline 1 & 95 & $28 \%$ \\
\hline 2 & 105 & $31 \%$ \\
\hline 3 & 137 & $41 \%$ \\
\hline
\end{tabular}

Table 5 shows distribution of the respondents according to the Number of their Pantawid Children. 137 respondents or $41 \%$ of the total sample have three (3) benefited children or Pantawid children, followed by 105 respondents or $31 \%$ of the total sample having two (2) Pantawid children and 95 respondents or $28 \%$ of the total samples have only one (1) Pantawid child.

Three (3) children per 4Ps beneficiary only were eligible to receive additional Php300 educational assistance for elementary and Php 500 educational assistance for high school, in which it affected the amount of grants they received.

Table 6. Demographic Profile according to Educational Attainment

\begin{tabular}{|l|l|l|}
\hline Educational Attainment & Frequency & Percentage \\
\hline $\begin{array}{l}\text { ELEMENTARY } \\
\text { UNDERGRADUATE }\end{array}$ & 52 & $15 \%$ \\
\hline $\begin{array}{l}\text { ELEMENTARY } \\
\text { GRADUATE }\end{array}$ & 52 & $15 \%$ \\
\hline $\begin{array}{l}\text { HIGH SCHOOL } \\
\text { UNDERGRADUATE }\end{array}$ & 107 & $32 \%$ \\
\hline $\begin{array}{l}\text { HIGH SCHOOL } \\
\text { GRADUATE }\end{array}$ & 107 & $32 \%$ \\
\hline $\begin{array}{l}\text { COLLEGE } \\
\text { UNDERGRADUATE }\end{array}$ & 11 & $4 \%$ \\
\hline COLLEGE GRADUATE & 8 & $2 \%$ \\
\hline
\end{tabular}

Table 6 show Distribution of the respondents according to their Educational Attainment. In terms of educational attainment, Elementary Undergraduate and Elementary Graduate respondents were with the same number of 52 or $15 \%$ of the total sample, as well as the High School Undergraduate and High School Graduate respondents having the same number of 107 respondents or $32 \%$ of the total sample. College Undergraduate respondents were only 11 or $4 \%$ of the total sample and College Graduate respondents having only 8 or $2 \%$ of the samples.

Some respondents were dropped out for higher education. These may be due to individual issues or a mix of problems like financial problems, poor life preparation, they were undecided, conflict with work and family commitments and lack of support.

TABLE 7 shows the allocation of cash grants for Education. The Students Daily Allowance ranked at number 1 with 3.67 weighted mean, followed by School Uniform at number 2 with 3.58 weighted mean, School Supplies at number 3 with 3.55 weighted mean, School Projects at number 4 with 3.40 weighted mean, PTA Contribution at number 5 with 3.40 weighted mean and School Donations at number 6 with 3.28 weighted mean. 
The 4Ps beneficiaries highly prioritized the education of the children because it was the main purpose of the cash grants from the government. It was found out that the cash grants they received is always allocated at the above mentioned items with a composite mean of 3.48 .

Table 7.Allocation of cash grants with regards to Education

\begin{tabular}{|l|l|l|l|}
\hline INDICATORS & WM & DESCRIPTION & RANK \\
\hline $\begin{array}{l}\text { SCHOOL } \\
\text { UNIFORM }\end{array}$ & 3.58 & ALWAYS & 2 \\
\hline $\begin{array}{l}\text { SCHOOL } \\
\text { SUPPLIES }\end{array}$ & 3.55 & ALWAYS & 3 \\
\hline $\begin{array}{l}\text { SCHOOL } \\
\text { DONATIONS }\end{array}$ & 3.28 & ALWAYS & 6 \\
\hline $\begin{array}{l}\text { STUDENT'S } \\
\text { DAILY } \\
\text { ALLOWANCE }\end{array}$ & 3.67 & ALWAYS & 1 \\
\hline $\begin{array}{l}\text { SCHOOL } \\
\text { PROJECTS }\end{array}$ & 3.40 & ALWAYS & 4 \\
\hline $\begin{array}{l}\text { PTA } \\
\text { CONTRIBUTION }\end{array}$ & 3.40 & ALWAYS & 5 \\
\hline $\begin{array}{l}\text { COMPOSITE } \\
\text { MEAN }\end{array}$ & $\mathbf{3 . 4 8}$ & ALWAYS & \\
\hline
\end{tabular}

Table 8. Allocation of Cash Grants with regards to Food

\begin{tabular}{|l|l|l|l|}
\hline INDICATORS & WM & DESCRIPTION & RANK \\
\hline RICE & 3.02 & SOMETIMES & 1 \\
\hline LEAN MEAT & 2.51 & SOMETIMES & 4 \\
\hline POULTRY & 2.50 & SELDOM & 5 \\
\hline SEA FOOD & 2.41 & SELDOM & 6 \\
\hline $\begin{array}{l}\text { CANNED } \\
\text { GOODS }\end{array}$ & 2.72 & SOMETIMES & 3 \\
\hline VEGETABLES & 2.84 & SOMETIMES & 2 \\
\hline FRUITS & 2.38 & SOMETIMES & 7 \\
\hline $\begin{array}{l}\text { COMPOSITE } \\
\text { MEAN }\end{array}$ & $\mathbf{2 . 6 3}$ & SOMETIMES & \\
\hline
\end{tabular}

TABLE 8 shows the allocation of cash grants on Food. Rice was ranked number 1 with 3.02 weighted mean, followed by Vegetables at number 2 with 2.51 weighted mean, canned good at number 3 with 2.72 weighted mean, lean meat was ranked at number 4 with 2.51 weighted mean, poultry has a weighted mean of 2.50 and was ranked at number 5 , sea food was ranked at number 6 with 2.41 weighted mean and fruits was ranked at number 7 with 2.38 weighted mean.

It was found out that most of the respondents sometimes allocated their cash grants on food with a composite mean of
2.63. Foods were the basic necessity of every family. The above mentioned items were the basic foods that some families were afford to purchase.

Table 9.Allocation of cash grants with regards to Transportation

\begin{tabular}{l|l|l|l|}
\hline INDICATORS & WM & DESCRIPTION & RANK \\
\hline $\begin{array}{l}\text { TRICYCLE } \\
\text { FARES }\end{array}$ & 2.55 & SOMETIMES & 1 \\
\hline $\begin{array}{l}\text { JEEPNEY } \\
\text { FARES }\end{array}$ & 2.46 & SELDOM & 2 \\
\hline BUS FARES & 2.35 & SELDOM & 3 \\
\hline $\begin{array}{l}\text { COMPOSITE } \\
\text { MEAN }\end{array}$ & $\mathbf{2 . 4 5}$ & SELDOM & \\
\hline
\end{tabular}

TABLE 9 shows the allocation of cash grants on Transportation. It was revealed that in general, respondents seldom spent their cash grants on transportation with a composite mean of 2.45 .

Tricycle fares were ranked at number 1 with 2.55 weighted mean, Jeepney Fares gained a weighted mean of 2.46 and ranked at number 2 and Bus Fares were on the least as it ranked number 3 with 2.35 weighted mean.

Some Barangays of Laur, Nueva Ecija are not reachable by Jeepneys and buses and they sometimes allocated their cash grants on tricycle fares. Most of the respondents have their own transportation vehicle used for nearby places only.

Table 10.Allocation of Cash Grants with regards to Clothing

\begin{tabular}{|l|l|l|l|}
\hline INDICATORS & WM & DESCRIPTION & RANK \\
\hline $\begin{array}{l}\text { BUYING NEW } \\
\text { CLOTHES }\end{array}$ & 2.27 & SELDOM & 1 \\
\hline $\begin{array}{l}\text { BUYING } \\
\text { BRANDED } \\
\text { CLOTHES }\end{array}$ & 1.70 & NEVER & 3 \\
\hline $\begin{array}{l}\text { BUYING } \\
\text { CLOTHES FOR } \\
\text { FAMILY }\end{array}$ & 2.14 & SELDOM & 2 \\
\hline $\begin{array}{l}\text { COMPOSITE } \\
\text { MEAN }\end{array}$ & $\mathbf{2 . 0 4}$ & SELDOM & \\
\hline
\end{tabular}

Table 10 shows the allocation of cash grants on clothing. Respondents were seldom allocating their cash grants on buying new clothes as it gains 2.27 weighted mean and ranked at number 1 , seldom in buying clothes for their family with a weighted mean of 2.14 and ranked at number 2 and they never buy branded clothes as it gains a weighted mean of 1.70 and was ranked at number 3 . 
Some respondents stated that they buy clothes if their children request for it. Occasionally, as long as their clothes were presentable and decent, there is no need for them to buy a new one.

Table 11. Allocation of cash grants with regards to Entertainment

\begin{tabular}{|l|l|l|l|}
\hline INDICATORS & WM & DESCRIPTION & RANK \\
\hline SHOPPING & 2.00 & SELDOM & 2 \\
\hline $\begin{array}{l}\text { RECREATIONAL } \\
\text { ACTIVITIES }\end{array}$ & 2.03 & SELDOM & 1 \\
\hline FAMILY OUTING & 1.87 & SELDOM & 3 \\
\hline $\begin{array}{l}\text { FAMILY } \\
\text { VACATION }\end{array}$ & 1.76 & SELDOM & 4 \\
\hline $\begin{array}{l}\text { VISITING THEME } \\
\text { PARK }\end{array}$ & 1.76 & SELDOM & 5 \\
\hline $\begin{array}{l}\text { COMPOSITE } \\
\text { MEAN }\end{array}$ & $\mathbf{1 . 8 7}$ & SELDOM & \\
\hline
\end{tabular}

Table 11 shows the allocation of cash grants on entertainment.

Respondents were seldom allocating their cash grants on Recreational Activities ranked at number 1 with 2.03 weighted mean, Shopping ranked at number 2 with 2.00 weighted mean, Family Outing ranked at number 3 with 1.87 weighted mean, Family Vacation ranked at number 4 with 1.76 weighted mean and the least was Visiting Theme Park ranked at number 5 with 1.76 weighted mean.

In general, the respondents seldom allocated their cash grants on the above mentioned items with a composite mean of 1.87. This means that the respondents are seldom entertaining themselves using the cash grants.

Table 12.Allocation of Cash Grants with regards to Bills

\begin{tabular}{|l|l|l|l|}
\hline INDICATORS & WM & DESCRIPTION & RANK \\
\hline WATER BILLS & 2.27 & SELDOM & 2 \\
\hline $\begin{array}{l}\text { ELECTRICITY } \\
\text { BILLS }\end{array}$ & 1.98 & SELDOM & 3 \\
\hline $\begin{array}{l}\text { HOUSE } \\
\text { RENTALS }\end{array}$ & 1.52 & NEVER & 4 \\
\hline $\begin{array}{l}\text { CELLULAR } \\
\text { LOADS }\end{array}$ & 2.32 & SOMETIMES & 1 \\
\hline $\begin{array}{l}\text { COMPOSITE } \\
\text { MEAN }\end{array}$ & $\mathbf{2 . 0 2}$ & SELDOM & \\
\hline
\end{tabular}

Table 12 shows the allocation of cash grants on Bills. Cellular Loads were ranked at number 1 with 2.32 weighted mean, Water Bills ranked at number 2 with 2.27 weighted mean, Electricity Bills ranked at number 3 with 1.98 weighted mean and House Rentals ranked at number 4 with 1.52 weighted mean.

Some respondents were seldom allocating their cash grants on water bills because not all the barangays in Laur Nueva Ecija have potable water line. Most respondents were seldom allocating their cash grants on Bills because they were rarely using it every day.

Table 13. Summary of Allocation of Cash Grants

\begin{tabular}{|l|l|l|l|}
\hline INDICATORS & WM & DESCRIPTION & RANK \\
\hline EDUCATION & 3.48 & ALWAYS & 1 \\
\hline FOOD & 2.63 & SOMETIMES & 2 \\
\hline TRANSPORTATION & 2.45 & SELDOM & 3 \\
\hline CLOTHING & 2.32 & SELDOM & 4 \\
\hline ENTERTAINMENG & 1.87 & SELDOM & 6 \\
\hline OTHER BILLS & 2.02 & SELDOM & 5 \\
\hline
\end{tabular}

The researchers concluded that the cash grants were always allocated as follows:

a) For Education with a composite mean of 3.48, in which Students Daily Allowance being highly prioritized with a weighted mean of 3.67.

b) Food gained a composite mean of 2.63 , Rice was prioritized with a weighted mean of 3.02 .

c) As to Transportation that gained a composite mean of 2.45, Tricycle fared were prioritized with a weighted mean of 2.55 .

d) As to clothing that gained a composite mean of 2.04, Buying New Clothes were slightly prioritized with a weighted mean of 2.27 .

e) As to entertainment that gained a composite mean of 1.87, Recreational Activities were slightly prioritized with a weighted mean of 2.03 .

f) As to bills that gained a composite mean of 2.02, Water Bills were prioritized with a weighted mean of 2.27 .

Based from the findings and conclusions presented, the following are the recommendations:

\section{Government/Local Government Unit (LGU)}

1. The Government should search for more poor qualified families to be their beneficiaries especially those family 
living in far places who has limited accessibility with other benefits from the government.

2. The government should provide financial education on the 4Ps beneficiaries for them to be more knowledgeable on how to budget their cash grants.

3. The national government should work hand-in-hand together with the barangay officials for monitoring and coaching of the 4 Ps Beneficiaries.

\section{Brgy. Officials}

1. The Brgy. Officials should have a Livelihood Programs and Activities for 4Ps families to help them have an extra income and not just to be a dependent on the subsidy.

\section{Ps Beneficiaries}

1. 1. The 4Ps beneficiaries must keep their children in school to continuously receive the cash grants from the government.

2. 2. The 4Ps beneficiaries should allocate their cash grants on important needs only such on education and food. Cash grant management should be thought to them so that proper allocation will be practiced, a financial education program might help them.

3. 3. The 4Ps beneficiaries should also find alternative source of income to continuously provide other needs of their family.

\section{Researchers}

1. For the future researchers, they should conduct a further study to have a wide knowledge and understanding about this topic.

2. The future researchers can use this study as guide in the establishments of other researchers related to the topic stated.

\section{ACKNOWLEDGEMENT}

The researchers would like to thank their colleagues and students from NEUST who provided vision and proficiency that greatly assisted the researchers, furthermore, the researchers would like to thank their families who provided so much provision and understanding in completion of this research paper.

\section{REFERENCES}

[1] "Malacanang happy over success of PantawidPamilyang Pilipino Program" Retrieve - 2012-10-28
[2] "Conditional Cash Transfer (CCT) Philippines - Improving the Human Capital of the Poor (PantawidPamilyang Pilipino Program or 4Ps)" (PDF) Retrieve - 2012-10-28

[3] Institute of Family Life and Children's Studies - Philippine Women's University Taft Avenue, Malate, Manila "Beyond Compliance a Look into the Behavioral and Social Outcomes of the Pantawid Pilipinong Pamilya Program" Retrieve 2016-10-6

[4] Malaluan,Arnold Q.,Malaluan, Gleziel M., Layesa, Regine T., Malayba, Kathleen H., and Perez, Marisa H., Batangas State University Lipa City Campus, Brgy. Marawoy, Lipa City, Philippines, Financial Priorities of 4p's Beneficiaries: An Assessment Using First Bucket Theory

[5] Flores MJ, S., Espinoza CA, B, Enrico H, C, and Casimiro R, R. (2015), PantawidPamilyang Pilipino Program (4Ps): Its Effect on the Academic Performance of Student-Beneficiaries in Calaba National High School in the Philippines

[6] Casco J.J.M., L, Lam J.J., L, Lumantas K.J., V.and Magno J.E., C. (2015) ,The Impact of PantawidPamilyang Pilipino Program on Civic Engagement: A Propensity Score Matching Approach

[7] Frufonga R. F, 2016, The PantawidPamilyang Pilipino Program (4Ps) in Iloilo, Philippines: An Evaluation

[8] https://pantawid.dswd.gov.ph/

[9] https://psa.gov.ph/poverty-press-release/nid/53187 